\title{
Autofiction and Shishōsetsu: Women Writers and Reinventing the Self
}

\author{
Justyna Weronika Kasza
}

Henry Miller, Philip Roth, Paul Auster and Milan Kundera have all used themselves as their own aliases. When men do it, it is called metafiction and part of their playful experiment. When women do it, it is called autobiography.

-Jeanette Winterson

In this chapter, I set out to consider whether and to what end the Japanese shishosetsu (the I-novel) can be approached as a form of autofictional writing. In so doing, I will propose a model for thinking about autofiction that accommodates the Japanese tradition, which, for various reasons, has remained on the "periphery" of research on autofiction. This model is shaped not only by the need to extend the focus of conversations around autofiction beyond the dominant circle of French or Anglophone literature, but to broaden the frameworks of literary genres in the age of the global novel and to implement, where possible, more wide-ranging

J. W. Kasza $(\bowtie)$

Department of Foreign Language Studies, Seinan Gakuin University, Fukuoka, Japan

(C) The Author(s) 2022

A. Effe, H. Lawlor (eds.), The Autofictional, Palgrave Studies in Life Writing, https://doi.org/10.1007/978-3-030-78440-9_13 
interpretative perspectives. My discussion of the relationship between shishosetsu and autofiction will focus primarily on the role of language, with a particular focus on linguistic structures and the use of pronouns, in the process of creating narratives that center around the self and selfrepresentation. I will consider the ways in which Japanese shishōsetsu integrates vocabulary that both reveals and conceals the identity of the writing persona, in an attempt to create a reliable and, at the same time, fictitious testimony of the self. The capacity to "reinvent" the self through the text is an integral feature of both shishosetsu and autofictional writing, as, in turn, is the constant shape-shifting and transformation of the forms themselves.

The lack of a clearly delineated theoretical framework is what allows autofiction to assume or influence a variety of different forms. Exploring shishosetsu as one such form enables us to acknowledge the contribution that such texts make to redefining the status of life narratives not only in national literature but in the context of world literature. Yet, what are the grounds for the comparison between literary genres? What should be the point of departure, the criteria, the merits that enable us to approach shishosetsu and autofiction comparatively, or at least, to suggest parallels and similarities? The review of existing studies in shishōsetsu demonstrates how few attempts have been made to extend its scope beyond Japanese literature. The dominant tendency is to treat shishosetsu as a form unique to the Japanese literary tradition, and by doing so, studies often overlook the possible cross-cultural influences. There has, however, been some attempt to investigate the similarities between shishōsetsu and autobiography. To position shishosetsu against the background of general theories of "life writings," Irmela Hijiya-Kirschnereit, the author of the most substantial monograph on shishōsetsu available in English to date, observes,

Instead of "autobiography," which is often based, albeit unconsciously, on a European notion of the term, it would be wiser to speak of "autobiographical writing," or even use some of the recent general notions like "lifewriting," "life narratives," or "self narratives" in the case of Japan with its large number of different genres potentially falling into this category. A notion like "first person writing" [...] would not be applicable to the Japanese case with its wide range of linguistic possibilities to express agency and subject. For strategical and practical reasons, the term "autobiography" is retained here and is used in the wider sense of autobiographical writing to indicate its function as an umbrella term for a large scale of styles and forms of writing the self in Japan [...] We understand autobiography in the Japanese context as an autonomous text in which a person records his or her 
experiences over a larger span of his or her life. (Hijiya-Kirschnereit $2019,1059)$

Donald Keene explores the question I briefly touched upon before, that is, the translatability of shishosetsu and other literary genres representing life-writing narratives in Japan. To illustrate the extent of both linguistic and semantic challenges, he applies the notion of "aporetics of translation," and considers the particular problem posed by the firstperson pronoun:

If we want to translate shishōsetsu into English, how should we translate the pronoun "watashi"? In Chinese, we say "wo," in English we only have the pronoun "I" but in Japanese we can use multiple pronouns, like "boku," "watashi" or even "ore" and they all mean "I" (Keene 2014, 40). ${ }^{1}$

Keene explains here how the ambiguity of the grammatical pronouns in Japanese, especially the pronoun "watashi" ("I"), affects the translation process, making it even more difficult for a foreign reader to adequately distinguish the plurality of voices within the narrative. The key feature of shishosetsu to which Keene refers is the difference between "watashi" and "jibun" ("I" and "myself"), which can imply both the first-person singular ("I") and the third-person singular ("he/she," although no clear gender distinction is possible in the Japanese language) or, depending on the context, even the plural ("we").

Through the comparison I will undertake in this chapter, I will explore how Japanese writers expand the frameworks of self-narrations by creating literary forms situated somewhere "in-between" autofiction and shishōsetsu. The relationship between these two forms has grown in importance in light of several recent studies in Japan that point to a number of similarities between shishosetsu and autofiction. In the following section, I will briefly outline the characteristics of shishosetsu and its position in the history of Japanese literature in order to show how the specificity of the Japanese language determines the ways in which the self is incorporated in this form. 


\section{ShishōSETSU AND the Ambiguity of the SELF}

Shishosetsu occupies an important place in the history of Japanese literature. Male writers of the early twentieth century were the dominant force behind its development. Early studies conceive shishosetsu as both a literary genre and as a mode of reading fictional texts that accentuates the relationship between language and the process of (re)inventing the self in literature. More recent studies on shishosetsu in Japan have extended the scope of existing scholarship by emphasizing that the form originates in the specificity of the Japanese language: the lack of a fixed and stable pronoun "I" has offered the opportunity for creativeness, originality, and inventiveness in expressing the self. This, in turn, raises further questions as to whether a biographical approach is the only possible cognitive path applicable to shishosetsu. To what extent, we might ask, is the "I" in shishosetsu biographically loaded ${ }^{2}$ Does the "I" refer equally to the narrator, the character, and the writing persona? In order to answer this question, we would need to explore the differences between the Japanese notions of sakusha (author) and sakka (writer), differences that must be taken into consideration when discussing the specificity of the genre and the problem of authorship in Japanese literature more generally. As the editors of the seminal collection Shishōsetsu Handobukku (The Shishōsetsu Handbook) observe:

Without shishōsetsu, we would not be able to talk about Japanese literature anymore. Shishōsetsu was proudly created by the Japanese people. It developed from and through the characteristics of the Japanese language and culture, becoming a tool we use to express human nature and seize the moment through words. It occupies the most secure position in Japanese culture. (Akiyama and Katsumata 2014, 1)

The above statement exemplifies the direction that recent studies have taken, that is, searching for the origin and sources of shishosetsu in the language itself, instead of perceiving it either as the individual choice of the author or as a literary trend. To a certain degree, these studies argue that the characteristics of the Japanese language determine and condition the narrating process. This line of thinking also underpins the analysis I undertake in this chapter, because, as I argue, the linguistic conditions (both its possibilities and limitations) shape the ways in which the writers on which I will focus reinvent their selfhood within the narrative. 
Another noteworthy view is represented by Umezawa Ayumi in her study Shishōsetsu no gihō: Watashi katari no byakunen shi (The Structures of Shishosetsu: 100 Years of Narrating the "I", 2017), where she differentiates between six types of "selves" (the "I") explored by the authors of shishösetsu. Umezawa focuses on literary examples from the beginning of the twentieth century up to the present day and discusses the flexibility of the Japanese language to modify, create, recreate, alter, adjust, and transform the self in the narrative, which require our attention in the process of studying shishōsetsu. Umezawa emphasizes the diversity of shishōsetsu writing by suggesting that just as there is no one figure of the "I" in Japanese (I shall return to this discussion in the section below), there is no one established and dominant pattern of shishōsetsu writing.

Attention has been drawn in recent studies on shishosetsu to various literary genres, styles, and conventions, including graphic novels (manga), protest songs, and even poetry. This, in turn, has paved the way for a more inclusive, comparative, and cross-cultural reading of shishosetsu, which is no longer limited to prose narrative, as its traces are detectable in other literary forms. The authors of Shishosetsu Handobukku suggest that in the age of the global novel, it is paramount to approach literature crossculturally, beyond one's own mother tongue or literary traditions. This might be perceived as contradictory to the approaches discussed above, which accentuate the interconnection between the Japanese language and shishōsetsu style. Nonetheless, by expanding the scope of the analyses into other forms of life-writing narratives, including autofiction, Japanese researchers have also pointed to the aspect of "untranslatability," or more precisely "untransferability," that emerges as a result of comparative analysis. The question is: what happens with the narrating subject, the "I" (watashi), when it is translated into foreign languages? As most researchers suggest, neither the English "I," the French "je," nor the German "Ich" are the direct and accurate translations of the Japanese "watashi." The issue of "untranslatability" was the rationale behind Mizumura Minae's bilingual novel, discussed later in the chapter, which, by incorporating both Japanese and English into the narrative, emphasizes the ambiguity of the self.

Ōhara Norisaki, who attempts to redefine shishōsetsu in the context of global literature by way of extensive references to European fiction, deems autofictional writing the most compatible with the shishosetsu style. With reference to Serge Doubrovsky's reinvention of Lejeune's autobiographical pact, Ōhara draws out the points of convergence between the Japanese 
shishosetsu and French autofiction. Focusing on the flexible treatment of personal experiences in both forms and on the playful relationship between the narrator, character, and the writing persona, Ōhara observes that the fictionalization of the self is an essential element of both genres and reminds us that neither shishosetsu nor autofiction needs to be narrated in the first person.

The three contemporary Japanese women writers I will discuss are not straightforwardly aligned with the shishosetsu tradition, by which I mean the form it took during its boom in the 1920s and 1930s, when its popularity and practice were at their peak, and when it was regarded as a confessional form (close to autobiography or the autobiographical novel) that assumes coherence between the author, narrator, and character, with biographical references within the narratives. As I intend to demonstrate in the sections that follow, the female writers in question break with this conventional pattern of shishosetsu in how they reinvent the self (or to be more precise, incorporate the image of the self) in their stories by using the potential of the Japanese language to reveal and conceal, to cover and discover, the multiple forms of selfhood.

I argue that these writers extend the shishosetsu form into other literary genres, including autofictional writing. I set out to re-examine shishosetsu cross-textually, that is, to trace the supposed elements of life-writing narrative and (auto)biographical motifs across texts by Kanai Mieko, Sagisawa Megumu, and Mizumura Minae. ${ }^{3}$ Kanai's narratives oscillate between reality and fantasy, with frequent references to the Japanese imaginary and folktales. Sagisawa, affiliated with the underground movement of the 1980s, crosses the boundaries of national identity as a Japanese woman who discovers her Korean heritage, but she can do so only by writing from the perspective of the male narrator who, as she reveals in her stories, resembles the figure of her father. Mizumura, for her part, reflects on the notion of the translatability and untranslatability of the self as it is experienced by a bilingual writer, one whose constant transitions between English and Japanese cause her to lose the sense of her mother tongue.

Before proceeding with my analysis, I will summarize the key premises of shishosetsu writing in order to reconsider the extent to which these works might be compatible or comparable with autofiction. A concise definition of shishosetsu is provided by Edward Fowler, who explains: 
The shishōsetsu, narrated in the first or third person in such a way as to represent with utter conviction the author's personal experience, is riddled with paradoxes. Supposedly a fictional narrative, it often reads more like a private journal. It has a reputation of being true, to a fault, to "real life"; yet it frequently strays from the author's experience it allegedly portrays so faithfully. Its personal orientation makes it a thoroughly modern form; yet it is the product of an indigenous intellectual tradition quite disparate from western individualism. (Fowler 1988, 6)

Tomi Suzuki, on the other hand, states that "the 'I-novel' is not a given form of text that can be objectively identified, but a historically constructed reading mode and cultural paradigm that not only regulated the production and reception of literary texts but also defined cultural identity and national tradition" (Suzuki 1997, 24).

Despite its prominent position within the literary tradition of Japan, a number of contemporary writers express a distinctly ambivalent attitude toward shishosetsu. A further parallel emerges here with autofiction, which is also often rejected as a label by the authors to whom it is applied. An interesting example in the case of shishosetsu is Murakami Haruki, who in the Introduction to The Penguin Book of Japanese Short Stories, published in 2018, bluntly expressed his attitude toward Japanese literature in the following terms: "In my case, my only allergy is to Japan's so-called 'I -novel' - the form of autobiographical writing that has been at the forefront of Japan's modern fiction since the turn of the twentieth century [... My 'I-novel allergy' was also quite strong back then $[\ldots]$ and since you can't hope either to make your way through or to understand modern Japanese literature if you're going to avoid its constitutional predisposition to producing 'I-novels', I made a conscious effort while young to avoid going anywhere near Japanese literature" (Murakami 2018, xi). Polarized views on shishosetsu and its impact on Japan's literary landscape continue not only with the new names being "added" to the shishosetsu canon but also through new interpretative pathways and more inclusive and cross-cultural approaches to the genre. Despite its polemical status, shishōsetsu is nevertheless considered by leading Japanese scholars as one of the most remarkable literary genres in Japanese literature, and for many years has been perceived as the least translatable or transferable into another cultural sphere. As Fowler has noted, "shishosetsu will always occupy the heartland of language and literature in Japan" (Fowler 1988, 298). 
Perhaps the most important aspect of shishosetsu, when considering its relation to autofiction, is the ambiguous treatment of the first-person pronoun in Japanese, a complexity that is lost in the translation process. The self in Japanese language is relational, context-dependent, unstable, and defined by the situation. On the level of a sentence, the subject is usually omitted and only the context (with the application of proper grammar structures) will notify the listener or the reader of the identity of the speaker, as well as the latter's number (either singular or plural), and, in some cases, their gender. There are two words in Japanese that designate the notion of "I": "watashi" and "jibun." While the first means the public self and is emotionally neutral, the latter is often regarded as the intimate self, and as emotionally loaded. Of particular importance is the fact that Japanese grammar does not require pronouns in the sentence: the context and appropriate verb form reveal the identity of the speaker or the person to whom they refer. How, then, are "watashi" and "jibun" deployed in the narratives, and how do they affect our reading of texts as possibly autofictional? I will explore this specifically in relation to Sagisawa Megumu's work, considering how she differentiates "watashi" from "jibun" in her texts.

What needs to be reiterated here is that shishosetsu is not the reflection of the self (subjectivity) in the writing. In Japanese, the third-person pronoun could be (and is) in many instances read as "I." As much as the discovery of the confessional literary form was a turning point for Japanese literature in the second half of the nineteenth century (shishosetsu scholar Akiyama Shun considers Jean-Jacques Rousseau's Confessions as the key text in this transformation), and would ultimately transport it onto the platform of world literature, most scholars agree that shishosetsu is an indigenous convention in Japanese literature which derives directly from the language. The linguistic context and the characteristics of a language are also the focal point of Barbara Cassin's monumental study Dictionary of Untranslatables, where she distinguishes between "I," "me," and "myself," and refers to these as follows: "Having an I, being a person" (Cassin 2017, 463). Referring predominantly to French language (with some reference to other languages, including Japanese), she discusses the "path" from "moi" to the "self" and from "self" to "soi." The focus on semantic levels of "selfhood" in Cassin's method is the result of her background in philosophy of language, which determines her definition of "selfhood" as being anchored, first and foremost, in language itself. 
Cassin's methodology, in treating language (and the question of translatability) as the point of departure in discussing the notion of "selfhood," to a certain degree resembles my own line of interpretation of works by Kanai, Sagisawa, and Mizumura.

The application of Cassin's method, that is, a focus on the tools offered by language in the expression of the self, clearly reveals that the very concepts of selfhood in modern and postmodern thought have produced a number of conceptual terms and ideals that overlap but also frequently contradict each other. One area of this confusion is the blurred distinction between "self" and "identity," concepts which are often used interchangeably. Anthony Elliott, the author of Concepts of the Self, observes that it was the interference of language (or the linguistic approach to selfhood) that led to the confusion between selfhood and identity, whereas, as he argues, these two notions need to be clearly separated and defined based on their different cognitive premises (Elliott 2006, 18). The following parts of the chapter deal with select examples of the treatment of the "self" in works by three Japanese women writers. I propose that three patterns of self-representation emerge in these texts: the metamorphosed self (Kanai Mieko), the transgender self (Sagisawa Megumu), and the bilingual self (Mizumura Minae).

\section{The Metamorphosed Self: Kanai Mieko}

Kanai's 1973 story Usagi (Rabbits) is inspired by Lewis Carroll's novel Alice in Wonderland. There are clear references to this classic novel but the entire narrative is supplemented by a number of metaphorical expressions and by Kanai's boundless imagination. Usagi is not the only work by Kanai that epitomizes her creativeness and brave attempt to challenge literary conventions. Her departure from realistic narrative toward fantasy, with recourse to myths and folktales, has become the hallmark for a younger generation of Japanese female writers, including Tawada Yōko, Kawakami Mieko, and Kawakami Hiromi. Much of Kanai's literary criticism and reflections on Japanese literature makes comparisons between women's writing in Japan and in Western literature, principally in French writing. Her affiliation with the shishōsetsu tradition remains problematic, as is true of most post-war Japanese authors. She never labels her writing shishōsetsu, yet she constantly uses the terms "jiko hyōgen" (the expression of the ego) or "jiko kakunin" (the confirmation of the ego), thus positioning her writing somewhere in-between fiction and autobiography. Both in 
her fiction and in her critical texts, Kanai demonstrates a keen attention to word choice: she understands that in order to showcase the full capacity of her imagination and writing skills, she needs to offer a new picture of the writing self. As she confessed in one of her interviews: "I want to be read without being seen as a female writer" (cited in Hijiya-Kirschnereit 2018, 259).

It is by reading her fiction alongside her non-fiction texts that Kanai's intentions become clear. While she wants to distance herself from "genderbased" interpretations of her works, she is nonetheless aware that female writers in Japan of her generation need a new space, and possibly new linguistic tools. In one of her essays, "Onna ni totte onna to wa nani ka?" (What Are Women to a Woman?), published in 1972, she draws out the different expectations for female- and male-authored works:

For men, behaviour such as delving into and narrating one's life experiences is at once considered tantamount to the work of a novelist. I, however, have been told that it is important for me to write about being "a woman" while listening to others' experiences of being "women"-probably because it is thought that the problems faced by being "a woman" become clearer when "women" delve into them together. Although male novelists who write about the experience of the self are not at all interesting, at least their perspective in writing is not narrowed to probing into what it means to be "a man." Why is it that only women must continue to write about being "a woman"? (cited in Osborne 2019, 95)

Representing a new wave in Japanese post-war literature that emerged in the middle of the 1970s, Kanai goes beyond the tradition of realistic, reliable narrative. By putting the ambiguous "watashi" at the center of her narration, she calls for constant redefinition of "josei no jibun," "the female self." In her interviews and commentary, she uses the Japanese term "jiko" ("ego"), which, more than "watashi" and "jibun," indicates the singularity of the self. However, as Kanai mentioned in one of her most recent interviews (2019), literature should not only serve as the confirmation of "selfhood"; the inventive, creative, and original potential of literature cannot be overlooked in the attempt to be a truthful storyteller. Usagi, alongside her other short stories, represents first and foremost the testimony of the writing self and the ongoing examination of the self as a writing persona. 
Usagi is, on the one hand, an exploration of what it means to be an author, and on the other, an exposition of the figure of the writing persona. The story touches upon the issue of identity with an openness rarely seen in Japanese literature. As we read in the opening, and probably the most telling part, of the story:

Writing (also not writing, since that is part of the whole process) means putting pen on paper and this I can do no longer. To write would seem to be my fate ... I wrote these words in my diary the day I pretty much forced myself to go out for a walk near my house [...]. Moving myself seemed a far more pleasant alternative than sitting inside and facing my diary, or all those pages of manuscript in my depressing room where the furniture still had to be put in place.

I was anyway in quite a foul mood. Even when wide awake, I felt as if I were in the midst of a bad dream [...]. Something undefinable, something like an illusion followed me wherever I went.... (Kanai in Birnbaum, 1982, 2)

The main axis of the plot is transformation, or more precisely, the transition from the real to the imagined, from human to animal, to the rabbits of the title. An important and constantly recurring motif is the moment the narrator attempts to envision and understand her bizarre transformation into a rabbit. As she tries to recall the instant of the transformation, the line between humanity and being an animal becomes blurred. The metamorphosis of the self, is, as we find out over the course of the story, the consequence of her father's killing and cooking rabbits. Although the reasons behind his cruelty are not revealed, or, as the narrator states, "not remembered," we can interpret the story as a metaphor for the peculiar relationships within the family, namely, the relations between the narrator and her father and the absence of other members of the family. Though the entire story is full of understatements and at times the narrative seems to lack consistency, the following passage captures the moment of the narrator's metamorphosis:

Every day since then I have been haunted by the ghosts of the dead rabbits and have behaved like a large, one eyed rabbit. In short, I have clearly confirmed that I can never again return to the world of human beings. Looking back on it, I see that I had lived like a normal human being until the fourteenth of that month several years back. Up to that time, I had been like any normal school girl and had kept hidden my from my classmates everything 
about my father's strange tastes-that he killed rabbits and cooked them. (Kanai in Birnbaum, 1982, 14-15)

Kanai frequently uses the words "lost" and "found," which may suggest that, as the writer, the narrator, and possibly the protagonist of the story, she sees literature as a tool for regaining the self; her imagination and the eerie world that crosses the boundaries of rationality effect a shift from the inexpressive "watashi" (neutral "I") toward the more tangible, real, and truthful "jiko" ("ego"). Kanai's writing is an example of a playful approach to the question of subjectivity in contemporary literature. The intertwining of the worlds of animals and people, the role of the writer, and the collision of reality and imagination have become the trademark concerns of many contemporary women writers who seek to go beyond the conventional canon of shishosetsu as a typical narrative of the self.

\section{The (Mis)gendered Self: Sagisawa Megumu}

Two major novels by Sagisawa Megumu, Kakeru shōnen (The Boy Who Runs), published in 1992, and her last fictional work Watashi no hanashi (My Story), first published in 2002, just two years before her death by suicide, not only complement each other in terms of plot-the figure of the missing father and the (un)reliability of one's memory-but, more importantly, both indicate a subtle line between "the self" and "the other." As in the case of Kanai Mieko, Sagisawa never confirmed the truthfulness and reliability of her stories, and despite the unequivocal title of her last novel, "My Story," her works have only recently been explored as a variation of shishōsetsu and as unique examples of referentiality in modern Japanese fiction. Most scholars and critics have focused on other issues which shaped and defined her writing, especially the manifestation of her ethnic background, being of Korean descent in post-war Japan. For this reason, most research to date has overlooked those features of Sagisawa's writing that challenge conventional shishōsetsu and exemplify a unique understanding of the problem of the self in her fiction.

Again, similarly to Kanai, central to Sagisawa's reflection and literary sensitivity is the notion of "jibun," the intimate and true self, as opposed to "tasha," the other. She elaborates this issue in a thought-provoking interview which she conducts with herself: Sagisawa Megumu jishin ni yoru Sagisaw Megumu (Last interview by herself) (2004), where she explains how writing helped her uncover multiple layers of internal 
otherness: from the choice of her pen name, which sounds like a male name (her real name was Matsuo Megumi), to the otherness of her background, and finally the otherness that manifests itself in her fiction. As much as Kanai Mieko's works constitute the search for an authentic self through the power of imagination, Sagisawa seems to suppress the notion of selfhood and considers otherness to be the only truthful image of the self. We see this most clearly in the The Boy Who Runs, a seemingly simple story that belongs to the subgenre in Japanese literature called katei shosetsu (the domestic novel).

Owing to the principal subject matter of these texts, that is, the author's discovery of her ethnic background - which, as we find out in both stories, had been concealed from Sagisawa until she reached adulthood-critics suggest that they should be read together as Sagisawa's testimony on coming to terms with her complex identity, toward which she assumes a rather ambiguous attitude (see, e.g., Umezawa, Ihara, and Oki 2018, 454-455). In both novels, the narrator assumes a multi-layered and multiform subjectivity, shifting from "watashi" to "jibun," from male narrator to female character. Within this first-person narrative, the "I" remains unthinkable without "the other" (literally "you"— "anata" in Japanese-which appears and reappears in the story). This process can be described as the constant oscillation between "I-the other" and "I-you." "Watashi" ("I") used in the narrative does not refer to Sagisawa (the writing persona), even though it tells the story of the writer Sagisawa Megumu who, upon discovering the truth about her Korean origins, struggles to get some purchase on her experience through the narrative process. The deliberate (mis)gendering of her character indicates the necessity of "writing in disguise," which, for Sagisawa, is the sole means of achieving authenticity and truthfulness in fiction.

Watashi no hanashi is considered to be a shishosetsu, despite the author's explicit assertion that she abhors shishosetsu writing. The narrative is divided into three parts and spans from 1992 to 2005. The final part reveals Sagisawa's understanding of the self but also the notions that she sees as determining the perception of selfhood more broadly, namely, the question of literary truth. Sagisawa explained why she had decided to narrate her story from a male perspective in the following terms: "To make the main character a female would bring me too close to myself [jibun]. Thanks to male character, I could keep jibun and watashi parallel in my fiction" (Sagisawa 2015, 5). Moreover, Sagisawa is conscious of the 
challenges imposed by the Japanese language and explores these issues in her essay "Watashi to iu Jibun" (The I as the Self):

What does it mean to live in accordance with the self [Jibun rashiku ikiru]. What is "I" [watashi]? How can I live as "I"? I believe there are many people who face the same dilemma. With regard to myself, Sagisawa Megumu, as a writing persona, I refer the self to the relation with the other. This is what I understand as "living in accordance with the self." But why do we need the other in order to reconsider our selfhood?

$[\ldots]$ I am convinced that the world is made of the "I" and the "other that exists beyond myself" [Jibun igai no tasha]. In other words, no matter how solid and stable our "I" may seem, it always needs to be confirmed by the existence of the "other." If there is no other, the ego [jiko] cannot exist. What I mean here is that the "I" that becomes jibun can only live through the life of the other. (Sagisawa 2015, 5)

The critic Takemoto Toshio distinguishes three stages in Sagisawa's writing - "the strong-self confirmation," "the I determined by others," and "the ever-changing self" $(2015,182)$-whereby identity is never fixed. Takemoto approaches her stories through Paul Ricœur's concept of narrative identity, who stated: "To answer the question 'who?' [...] is to tell the story of a life. The story told tells about the action of the "who.' And the identity of this 'who' therefore itself must be a narrative identity" (Ricœur 1988, 246).

It might be argued that, as in the case of Doubrovsky's Fils (1977) or Annie Ernaux's Les Années (2008), Sagisawa's texts exemplify the therapeutic effect of autofictional writing: it is not a faithful account or a testimony of life, but rather stands against conventional autobiography, the story of life narrated in an orderly manner. But paradoxically, it is still "my story," retold, reimagined, reinvented through fiction. "I don't really know that myself," says the character of Sagisawa's story (Sagisawa 2005, 9). This uncertainty about her Korean identity is amplified by the metaphor of the character moving around Japan. Japanese, Korean, Zainichi (the Korean living in Japan): the simultaneous senses of belonging and alienation evoked throughout the text testify to the impossibility of Sagisawa's identity emerging in relation to just one of these three groups. We might expect the process of writing to bring some kind of consolation or resolution for Sagisawa in dealing with the otherness within the self. Instead, it brings the opposite: it signifies the moment when the narrator discovers that the integrity of the self does not exist. Writing initiates the process of 
breaking apart selfhood, creating what Paul Ricœur identified as the "shattered cogito" (Ricœur 1990, 11).

\section{The Bilingual Self: Mizumura Minae}

Published in 1993, Mizumura's Shishōsetsu from Left to Right interweaves English and Japanese. We follow the story of Minae, a Japanese girl, who moved to America at the age of 12. In the form of a conversation with her sister Nanae, Minae endeavors to come to grips with a "self" trapped in a bilingual reality. Shishosetsu from Left to Right is not a conventional life story. Read alongside Mizumura Minae's other works, including her extensive non-fiction works and interviews, this text is a treatise on the anthropology of the self. With an academic background in literary studies, not only does Mizumura recreate her life in narrative form, but she also attempts to explore to what extent "the self" is determined by language. In so doing, she seeks to determine whether shishosetsu-to which she refers directly in the title-has the potential to cross the boundaries of national literature and be written or read beyond the Japanese context. For Mizumura, the self is inseparable from the language that one speaks. She argues that language remodels the self and affects interpersonal relations. The text is often compared with works by other bilingual and translingual writers in Japan: Tawada Yōko, a Japanese writing in German, and Hideo Levy, an American writing in Japanese. These works form what has been termed "ekkyō bungaku," border-crossing literature, that is, literature written outside of the author's mother tongue, and they have contributed to the changing paradigm of thinking about national literature in Japan.

In numerous interviews, Mizumura has explained that the rationale behind her experimental narrative was to challenge the notion that the Japanese language is an integral part, if not a condition, of shishōsetsu. Her approach is something of a paradox: while she crosses the boundaries of so-called national literature by writing in two languages, she seems simultaneously to emphasize the unbreakable bond between the Japanese language and shishosetsu. The entire text serves as a re-evaluation of one's national heritage. Attempting to define her literary self, Mizumura moves constantly between what she considers to be her "own" cultural background and what she deems foreign. The following quotation, which I deliberately leave untranslated, illustrates how the two languages are used in the narrative. It is also an important turning point in the story: in a 
conversation with her sister, Minae, struggling with her identity (her Japanese "watashi" and the English "I") finally realizes that only writing in her native language, Japanese, can bring some kind of reconciliation, a similar remedy to the one that Sagisawa sought in her fiction when concealing her identity and writing as a male character.

I want to be a novelist. Oh yes? Are you going to write in English or in Japanese? こjいう会話は幾度か英語では繰り返したことがあったが、 奈苗に同じ質問をされるとは思わなかった。

一もちろん日本語でょ。

一そりやあなたが日本が好きになったのは分かるわよ。Boy， that's been your passion ... or rather your obsession for, oh, I don't how many years. Japanese this and Japanese that and I never hear the end of it. だけど 日本語を書くとなると、話は別じゃない。(Mizumura 1995, 112-113)

The novel's uniqueness lies in the use of Japanese characters in the parts that refer to the author's own self, while the rest of the text appears to be a random juxtaposition of English and Japanese. It can be described as "translating the self," that is, putting forward the "watashi" ("I") in Japanese rather than in English. Mizumura highlights the ambiguity of the self in the Japanese language and claims:

I did not lose my "Japanese" self and, so far as I used the Japanese language, that self continued to exist; I thought that the "I" in the Japanese language was what I was truly, and continued to live with the belief that I could easily retrieve it once I went back to Japan, because the "I" in the English language was something which hardly seems to me what I am. (cited in Nakai 2005, 25)

Summarizing the text, Mizumura reveals, "It is a how-I-became-aJapanese-writer story and that story necessarily runs parallel to the story of how I failed to become a writer in the English language" (Mizumura 2004).

\section{Shishōsetsu, Autofiction, and a New Model of National Literature}

Owing to the issues that surround both shishōsetsu and autofiction (questions of origin, scope, terminology, definition, translation), the comparison between the two genres may, unsurprisingly, produce a number of methodological challenges and problems. The question that has 
accompanied me while preparing this chapter is whether we can indeed discern a specifically Japanese form of autofiction. The current state of research in Japan indicates the growing importance of new perspectives and more inclusive, wide-ranging, cross-disciplinary approaches. Attempts made by some Japanese scholars to read shishösetsu "autofictionally" testify to possible new directions not only in cross-cultural but also in cross-textual interpretations. Whether we conceive of shishosetsu as a literary genre, or as a mode of reading, new voices from outside Japan and the Japanese language are playing a key role in recreating the notion of Japanese literature, expanding its borders toward world or global literature. ${ }^{4}$ It is not the purpose of this chapter to define the boundaries of shishosetsu, nor to indicate whether a given literary work is or is not an example of shishosetsu or autofiction. The texts discussed demonstrate that we are dealing with a type of writing whose criteria remain flexible, thus encouraging further solutions to the problem of subjectivity in a broad approach. The objective was rather to put shishōsetsu and autofiction into dialogue in order to enrich our understanding of both forms.

My comparative reading sheds new light on shishōsetsu as a form of writing and as a literary genre, one that exceeds the borders of Japanese literature. In the writings of contemporary French and Francophone writers such as Amélie Nothomb, Eric Fay, Philippe Forest, and Dany Laferrière, for example, we see an interesting attempt to integrate the features of autofiction with the aesthetics of Japanese literature or to include Japanese themes in their narrative (Kasza 2021, 217-235). Establishing the extent to which their works can be considered as autofiction or shishōsetsu remains problematic, as, in both forms, textual evidence and literary patterns are flexible and rely mostly on our "mode of reading." The writings of Kanai, Sagisawa, and Mizumura constitute important voices in further discussions on the state of life-writing narratives in Japan. Whether we refer to them as shishosetsu, autofiction, biofiction, or egofiction, they also demonstrate the multi-layered process of exploring the enigma of the self in literature when the Japanese language does not offer a fixed or stable sense of selfhood. But crucially, it is the deviation from patterns of conventional shishosetsu that has become the trademark of these women writers. The way in which all three female writers cross cultural, literary, and linguistic boundaries makes the untranslatable notion of shishosetsu transferable to the realm of world literature. 


\section{Notes}

1. Unless otherwise stated, all translations from the Japanese are the author's own.

2. It is important to note that "shi" is a Chinese reading of the character 私 and means "I." The Japanese reading of the same character is "watashi/ watakushi." For that reason, there are two possible ways of reading 私小説 as "shishōsetsu" or "watakushi shōsetsu."

3. Throughout the text, I follow the Japanese pattern: family name followed by first name.

4. I explore this topic in my latest monograph, The I in the Making: Rethinking the Japanese Shishōsetsu in a Global Age (2021).

\section{Works Cited}

Akiyama, Shun, and Hiroshi Katsumata. 2014. Shishōsetsu Handobukku [The Handbook of Shishōsetsu]. Tokyo: Bensei Shuppan.

Birnbaum, Phyllis, ed. 1982. Rabbits, Crabs, Etc.: Stories by Japanese Women. Honolulu, HI: University of Hawai'i Press.

Cassin, Barbara. 2017. Dictionary of Untranslatables: A Philosophical Lexicon. Translated by Emily Apter and Jacques Lezra, Michael Wood. Princeton: Princeton University Press.

Elliott, Anthony. 2006. Concepts of the Self. Cambridge: Polity Press.

Fowler, Edward. 1988. The Rhetoric of Confession Shishōsetsu in Early TwentiethCentury Japanese Fiction. Oakland, CA: University of California Press.

Hijiya-Kirschnereit, Irmela. 2019. Japan. In Handbook of Autobiography / Autofiction, ed. Martina Wagner-Egelhaaf, 1059-1086. Berlin: De Gruyter.

Kanai, Mieko. 1973. Usagi [Rabbits]. Tokyo: Shinchōsha.

- 1982. Rabbits, Crabs, Etc.: Stories by Japanese Women. Edited by Phyllis Birnbaum. Honolulu, HI: University of Hawai'i Press.

- 2018. "Joseisakka dato iu ishiki nashide yonde moraitai" [I want to be read not as a female writer]. Interview by Irmela Hijiya-Kirschnereit. In Jory $\bar{u}$ hōdan: Shōwa o ikita joseisakka tachi [The conversations on women's style: Japanese female writers who lived in Shōwa period], 259-285. Tokyo: Iwanami Shōten.

Kasza, Justyna Weronika. 2021. The "I" in the Making: Rethinking the Japanese Shishōsetsu in a Global Age. Berlin: Peter Lang.

Keene, Donald. 2014. "Shishōsetsu wa mirai no tameni" [The future of shishōsetsu]. In Shishōsetsu Handobukku [The Handbook of Shishōsetsu], ed. Akiyama Shun and Hiroshi Katsumata, 32-43. Tokyo: Bensei Shuppan.

Mizumura, Minae. 1995. Shishōsetsu from Left to Right. Tokyo: Chikuma bunkō. 
2004. Authoring Shishōsetsu from Left to Right. 91st Meridian 3 (2). https://iwp.uiowa.edu/91st/vol3-num2/authoring-shishosetsu-from-leftto-right/. Accessed Apr 7, 2021.

Murakami, Haruki. 2018. Introduction: From Seppuku to Meltdown. In The Penguin Book of Japanese Short Stories, ed. Jay Rubin, XI-XXXII. London: Penguin.

Nakai, Atsushi. 2005. Hybridity and Contemporary Japanese-Language Literature. Hitotsubashi Journal of Arts and Science 46 (1): 19-29.

Osborne, Hannah. 2019. The Ai-Novel: Ai no seikatsu and Its Challenge to the Japanese Literary Establishment. Japanese Language and Literature Journal of the American Association of Teachers of Japanese 53 (1): 95-121.

Riceur, Paul. 1988. Time and Narrative: Volume 3. Translated and edited by Kathleen. Blamey and David Pellauer. Chicago: University of Chicago Press.

. 1990. Oneself as Another. Translated by Kathleen Blamey. Chicago: The University of Chicago Press.

Sagisawa, Megumu. 1992. Kakeru shōnen [The Boy who Runs]. Tokyo: Bungeishunnju.

- 2004. Sagisawa Megumu jishin ni yoru Sagisawa Megumu [Sagisawa Megumu by herself]. Bungei Autumn, 109-119.

- 2005. Watashi no hanashi [My story]. Tokyo: Kawade Bunkō.

- 2015. Watashi to iu jibun [The I as the Self]. In NKH Rajio Gakush $\bar{u}$ memo. Issue 3 and 4.

Suzuki, Tomi. 1997. Narrating the Self: Fictions of Japanese Modernity. Stanford, CA: Stanford University Press.

Takemoto, Toshio. 2015. Constructing the Self in Megumu Sagisawa's and Miri Yu's Travelogues: A Case Study of Two Japan-Based Female Writers of Korean Origin. Contemporary Japan 27 (2): 169-188.

Umezawa, Ayumi. 2017. Shishōsetsu no gihō: "Watashi” katari no hyaku nen shi [The Structure of Shishōsetsu: 100 Years of Narrating the "I"]. Tokyo: Bensei Shuppan.

Umezawa, Ayumi., A. Aya Ihara, and Shimon Ok, eds. 2018. Watakushi kara kan'gaeru bungaku shi: Shishōsetsu to iu shiza [Literary History of the "I." The Shishōsetsu Perspective]. Tokyo: Bensei Shuppan. 
Open Access This chapter is licensed under the terms of the Creative Commons Attribution 4.0 International License (http://creativecommons.org/licenses/ by $/ 4.0 /$ ), which permits use, sharing, adaptation, distribution and reproduction in any medium or format, as long as you give appropriate credit to the original author(s) and the source, provide a link to the Creative Commons licence and indicate if changes were made.

The images or other third party material in this chapter are included in the chapter's Creative Commons licence, unless indicated otherwise in a credit line to the material. If material is not included in the chapter's Creative Commons licence and your intended use is not permitted by statutory regulation or exceeds the permitted use, you will need to obtain permission directly from the copyright holder. 